\title{
MAPK8 wt Allele
}

National Cancer Institute

\section{Source}

National Cancer Institute. MAPK8 wt Allele. NCI Thesaurus. Code C52878.

Human MAPK8 wild-type allele is located in the vicinity of 10q11.22 and is approximately $133 \mathrm{~kb}$ in length. This allele, which encodes mitogen-activated protein kinase 8 protein, plays a role in the induction of programmed cell death mediated by both tumor necrosis factor-alpha and ultraviolet radiation. 